\title{
Yhä ylöspäin?
}

Suomalaisen puurakentamisen kaavoitusperiaatteita etsimässä

Markku Norvasuo

Puukerrostalot edustavat julkisuudessa puurakentamisen kärkeä, mutta vain viisitoista vuotta aikaisemmin visioitiin vielä matalan puurakentamisen mahdollisuuksia. Artikkeli käsittelee matalan ja toisaalta korkean, kerrostaloihin perustuvan puurakentamisen edistämisen vaihtelua 1990-luvulta aina 2020-luvun alkuun. Erityisesti selvennetään matalan puurakentamisen suhdetta historialliseen puukaupunkiin sekä tiivis ja matala -nimellä tunnetun kaavoituksen periaatteen vaikutusta. Tarkastelu auttaa ymmärtämään, miksi matala puurakentaminen vaikutti 1990-luvun lopulta noin 2010-luvun alkuun, vaikka taustalla oli pitkäaikainen pyrkimys kehittää puukerrostaloja. Lopuksi pohditaan matalan puurakentamisen myöhempää vaikutusta ja tarkastellaan tapahtuneita muutoksia myös polkuriippuvuuden käsitteen avulla.

\section{Johdanto}

Puurunkoiset asuinkerrostalot - ja niiden ohella julkiset puurakennukset ovat merkittävästi kasvattaneet puun osuutta rakennusmateriaalina. Vaikka uusien puukerrostalojen osuus kaikesta kerrostalorakentamisesta on edelleen vain noin viisi prosenttia, määrä kasvaa voimakkaasti. Markku Karjalaisen mukaan puurunkoisia uudiskerrostaloja oli elokuun 2020 loppuun mennessä rakennettu yhteensä 103 kappaletta ja niissä oli 3052 asuntoa. Lähivuosina tuotantoa on valmistumassa yli 2300 asunnon verran, ja uusia asuinpuukerrostalokohteita vireillä noin 9000 asunnon verran. (Puurakentamisen edistämisen ja ohjauksen keinot kaavoituksessa -opas, 2020.) 
Puukerrostalojen kehittäminen Suomen olosuhteisiin alkoi kuitenkin jo 1990-luvun puolivälissä. Reippaan alun jälkeen niiden rakentaminen väheni ja taukosi välillä kokonaan, kunnes vuodesta 2011 alkoi jälleen elpyä (Puuinfo, 2019). Tässä suvantovaiheessa merkittävä osa puurakentamisen kehittämisestä suuntautui matalaan alueelliseen puurakentamiseen. Tapahtumaketju on siten ollut monipolvisempi kuin miltä se vaikuttaa katsomalla yksinomaan puukerrostalojen rakentamistahtia.

Tässä artikkelissa tarkastellaan, miten matalan ja toisaalta kerrostaloihin perustuvan korkean puurakentamisen edistäminen kaavoitusperiaatteineen niveltyivät toisiinsa 1990-luvulta aina 2020-luvun alkuun. Kyseessä ei ole kattava historiallinen selvitys, vaan huomio kohdistuu kahteen pääkysymykseen. Ensimmäinen ja tärkeämpi niistä koskee matalan puurakentamisen esikuvia ja kaavoitusperiaatteita, etenkin historiallisen puukaupungin ja toisaalta tiivis ja matala -nimellä kulkevan kaavoitusperiaatteen vaikutusta. Toinen kysymys liittyy siihen, kuinka matalan puurakentamisen edistämisestä siirryttiin kohti korkeampaa rakentamista puukerrostalojen yleistyessä jakson loppupuolella. Artikkelissa on toisin sanoen kaksi toisiinsa lomittuvaa näkökulmaa: ensinnäkin puukerrostalojen kehittäminen uuden puurakentamisen pitkäkestoisena teknologisena pyrkimyksenä ja toiseksi puurakentamisen kiinnittyminen historiaan, kaupunkirakentamisen muotoihin ja puun käyttömahdollisuuksiin.

Näiden kysymysten käsittely johdannon ja johtopäätösten välillä jakautuu neljään osioon. Niistä ensimmäisessä tarkastellaan käsitteellistä siirtymää historiallisesta puukaupungista "uuteen puukaupunkiin". Näkökulma on kriittinen, sillä vaikka vanhat puukaupungit vaikuttivatkin uuteen puurakentamiseen, vaikutus tulkitaan helposti liian suoraksi. Seuraava osio käsittelee tiiviin ja matalan rakentamisen lähtökohtia, joilla on yhteyksiä myös historialliseen puukaupunkiin, sekä aihetta käsittelevää tutkimusta. Tämän jälkeen palataan puurakentamisen edistämisen alkuvaiheisiin 1990-luvulla ja pohditaan erityisesti, miten puurakentamisesta tuli käytännössä osa tiiviin ja matalan edistämistä. Puukerrostaloihin palataan johtopäätöksiä edeltävässä osiossa. Siinä tarkastellaan puukerrostalojen rakentamisen vilkastumista 2010-luvulla ja vastaavasti tiiviin ja matalan periaatteiden jäämistä taka-alalle. Johtopäätöksissä koko kolmenkymmenen vuoden kehityskulku pelkistetään kahteen peräkkäiseen vaiheeseen. Polkuriippuvuuden käsite voi tällöin auttaa hahmottamaan tapahtuneita muutoksia.

Tutkimusmateriaalina on pääosin käytetty kirjallisia lähteitä, kuten tutkimusraportteja sekä tieteellisiä ja ammatillisia julkaisuja ja lehtiartikkeleita. Aineistoa on lisäksi täydennetty muutamilla puhelinkeskusteluilla tutkimuk- 
siin tai muuten aihepiiriin osallistuneiden kanssa. Näin on voitu selventää erityisesti 1990-luvun merkityksellisiä kehityskulkuja.

Historiallisen puurakentamisen määrittelystä ei yleensä ole epäselvyyttä, mutta uudessa puurakentamisessa puukerrostalon määritelmä edellyttää runkorakenteiden olevan puuta: "Puukerrostaloksi sanotaan taloa, joka on vähintään kaksikerroksinen, jonka kerrokset ovat tavallisesti eri huoneistoja ja jossa kantavat runkorakenteet ovat pääosin puuta. Puukerrostalot voivat olla puujulkisivuisia tai myös muilla julkisivumateriaaleilla verhottuja." (Tolppanen, Karjalainen, Lahtela \& Viljakainen, 2013, s. 10). Käytännössä suomalaiset puukerrostalot on yleensä myös verhottu puulla. Puurakennukset ovat siten selkeästi tunnistettavia kaupunkikuvassa riippumatta rakennuskorkeudesta.

\section{Historiallisesta puukaupungista uuteen puukaupunkiin}

Puurakentamisen oppikirjat ja yleisteokset alkavat tavallisesti jonkinlaisella johdannolla puurakentamisen taustoihin ja puun erilaisiin käyttötapoihin. Vallitsee siis yleinen ymmärrys siitä, että puurakentamisen historialla on merkitystä myös nykyajassa. Jouni Koiso-Kanttila (2002a, s. 9o) jopa toteaa: "Puu on aina ollut keskeisessä asemassa maamme rakentamisessa, jopa niin, että Suomen arkkitehtuurin historia voitaisiin paljolti kirjoittaa puunkäytön ja puumateriaaliin suhtautumisen kautta."

Hyvän esimerkin puurakentamisen monipuolisuudesta tarjoaa suurelle yleisölle tarkoitettu teos Kirkosta savusaunaan - puusta rakennettu Suomi (Böök \& Seppovaara, 2008). Sen kerronta ei noudata tavanomaisia puurakentamisen ryhmittelyjä vaan muodostaa koko Suomen kattavan matkareitin, jonka varrelle erilaiset ja eri-ikäiset kohteet limittyvät näennäisen sattumanvaraisesti. Omalla tavallaan teos havainnollistaa Koiso-Kanttilan yllä mainitun toteamuksen. Sisältö painottuu vanhaan rakennusperintöön, joten mukana on runsaasti kirkkoja, puukaupunkimiljöitä, julkisia rakennuksia sekä maaseudun kyliä ja asuinrakennuksia. Edustettuina ovat myös kartanot, pappilat ja huvilat ja myöhempänä kerrostumana seurantalot. Teoksen pohjavireenä on tunnistaa puurakentamisen perinteen monet muodot ja tarkastella niiden pohjalta puurakentamisen epävarmoja tulevia mahdollisuuksia. Uusinkin puurakentaminen on päässyt mukaan. Puisia asuinkerrostaloja edustaa Lahden Puu-Paavola. "Elpyykö puukaupunki?", kysyy teoksen viimeisen luvun otsikko. Puu-Paavolan kerrostalot olemassaolollaan vihjaavat tähän suuntaan, tosin hieman ironiseen sävyyn, sillä vanhan Puu-Paavolan "puutarhakaupunginosa" puutaloineen ehdittiin purkaa 1980-luvulla (Niskanen, 2015).

Käsitteen 'puukaupunki' voi kyseisen teoksen yhteydessä tulkita väljästi historiaan viittaavaksi, mutta sanalla on myös vakiintunut tarkkarajaisempi 
sisältö. Yksi merkittävimmistä jaksoista ennen nykyistä puurakentamista oli historiallisen puukaupungin "löytäminen". Vielä 190o-luvun alkupuolella puusta rakennetut alueet olivat suhteellisen yleisiä, mutta 1960-luvulle tultaessa monia vanhoja puutaloalueita uhkasi purkaminen. Puun asema rakentamisessa heikkeni muutenkin, kun puurakennusten osuus uudisrakentamisessa pieneni 43:sta 26 prosenttiin välillä 1957-1967 (siikanen, 1996, s. 13). Alkoi lähiöiden rakentaminen ja kaupunkialueiden laajeneminen suuren muuton seurauksena. Havahtuminen puukaupunkeja uhkaavaan hävitykseen johti prosessiin, jonka merkittävin ilmenemä oli Vanhan Rauman liittäminen UNESCOn maailmanperintöluetteloon vuonna 1991. Samalla vakiintui käsite pohjoismainen puukaupunki (Nordic wooden city). Tanja Vahtikari on olennaisin osin kuvannut tämän kehityskulun vuoden 2007 artikkelissaan "Miten Vanhasta Raumasta tuli maailmanperintökohde?".

Rauma, yksi Suomen kuudesta keskiaikaisesta kaupungista, sai kaupunkiprivilegiot vuonna 1442. Viimeinen laaja tulipalo kaupungissa oli vuonna 1682. Käsite "Vanha Rauma" sai varhaisen merkityksensä 18oo-luvun alussa, ja 1900-luvun alkupuolella Vanhan Rauman arvo alettiin tunnistaa valtakunnallisesti, mikä ilmeni myös vuonna 1938 aloitetussa asemakaavan laatimisessa. Siitä huolimatta vanhankaupungin aluetta uhkasi purkaminen 1960-luvun alussa. Vuonna 1964 pidettiin keskustakilpailu, jota seuranneessa kaavarungon valmistelussa tavoitteena oli vanhankaupungin yleisilmeen, mittakaavan ja katuverkon säilyttävä uudistaminen. Kuitenkin jo 1970-luvun alussa tätä valmistunutta kaavarunkoa alettiin pitää vanhentuneena: "Siirtymä olemassa olevan rakennuskannan laajalti säilyttäviin kaavoitusperiaatteisiin tapahtui Vanhan Rauman osalta melkein huomaamatta." Vuonna 1981 hyväksytty asemakaava vaati 60 prosenttia rakennuskannasta ehdottomasti säilytettäviksi. (Vahtikari, 2007, s. 100-105.)

Nimenomaan Vanhan Rauman valinnasta maailmanperintökohteeksi oli Vahtikarin mukaan sovittu Suomen, Ruotsin ja Norjan kesken, joissa kaikissa "puukaupungista oli tullut kansallisen kulttuuriperinnön kaanoniin kuuluvaa vakituista ainesta jo viimeistään 1960- ja 1970-lukujen taitteessa”. Vanha Rauma edustikin yhteensä 150 pohjoismaisen puukaupungin joukkoa. Suomen osalta valinta tehtiin Vanhan Rauman ja Vanhan Porvoon välillä. (Vahtikari, 2007, s. 105-108.)

Jokseenkin samanaikaisesti kuin Vanhasta Raumasta tuli maailmanperintökohde, virisi kiinnostus puurakentamisen tulevia mahdollisuuksia kohtaan. Tällöin on luontevaa kysyä, miten historiallinen puukaupunki vaikutti uuden puurakentamisen kehittämiseen 1990-luvulta eteenpäin. Yhden tulkinnan tarjoaa Kalakosken, Huuhkan ja Koposen (2020) artikkeli, jossa vaikutus katsotaan vahvaksi. Tällaiseen tulokseen päädytään menetelmällä, jossa edellä kuvattu 
pohjoismaisen puukaupungin kanonisoinnin prosessi sovitetaan Juan Pablo Bontan modernin arkkitehtuurin kanonisointia koskevaan tulkintamalliin. Alun perin Bonta (1979) tutki 19oo-luvun arkkitehtuurin modernin suuntauksen tulkintaa rakennusten kautta eri vuosikymmenten kirjoituksissa ja näiden tulkintojen kanonisointia. Esimerkki tällaisesta rakennuksesta on Saksan paviljonki vuoden 1929 Barcelonan maailmannäyttelyssä. Hänen pohdintansa on huomattavan laaja sekä materiaaliltaan että näkökulmiltaan, mutta se voidaan kiteyttää yhdeksään vaiheeseen. ${ }^{1}$ Kalakosken ja muiden kirjoittajien artikkelin pääsisältö koskeekin tämän tulkintakehyksen siirtämistä uuteen, rakennusperinnön muodostumisen yhteyteen. Tällöin kirjoittajat päätyvät tulkitsemaan myös pohjoismaisen puukaupungin ja 1990-luvun puurakentamisen suhteita. Tätä osuutta voi arvioida ilman Bontan mallin soveltamisen syvempää tarkastelua.

Vahtikarin tavoin Kalakoski ja muut (2020, s. 795-80o) toteavat puukaupungin käsitteen saaneen nykyisen merkityksensä 196o-luvulla. Tunnistettiin vanhojen puukaupunkialueiden suojelun tarve ja alettiin arvostaa puun ominaislaatua kaupungeissa. Puukaupungin käsite tuli myös arkkitehtien tietoisuuteen erityisesti Arkkitehti-lehden julkaistua Puukaupunki-teemanumeron vuonna 1972. Kirjoittajat katsovat kuitenkin (Vahtikarista poiketen), että 1960- ja 1970-lukujen diskurssi oli Bontan termein vielä esikanonisessa vaiheessa. Kanonisoidun aseman se saavutti 1980-luvun puolivälissä. Jo tätä ennen oli huolestuttu taitamattomasta korjaus- ja täydennysrakentamisesta. Kalakoski ja muut mainitsevat muun muassa ruotsalaisesta alkuteoksesta suomennetun Sture Balgårdin teoksen Täydennysrakentaminen puukaupungissa (1982) sekä Henrik Liliuksen teoksen Suomalainen puukaupunki (1985), joka toi puukaupunkiperinnön yleiseen tietoisuuteen ja laajemman keskustelun kohteeksi. Vanhan Rauman maailmanperintökohteeksi hyväksymisen jälkeen ilmestyi useita muitakin julkaisuja, jotka Kalakosken ym. mukaan kuuluivat jo kanonisoinnin jälkeiseen disseminaation vaiheeseen.

Uuden puurakentamisen kannalta mielenkiintoisin osuus koskee artikkelin loppuosaa, joka käsittelee 1990-luvun lopulla virinnyttä kiinnostusta puurakentamisen uudisalueisiin. Monet uusista puutaloalueista toteuttivat tuolloin tiiviin ja matalan periaatetta. Kalakoski ja muut katsovat tällöin alkaneen periodin merkinneen puukaupunki-käsitteen olennaista uudelleentulkintaa (reinterpretation yhtenä Bontan nimeämistä vaiheista). Ensinnäkin he kiinnittävät huomiota siihen, että myös 1990-luvun uusia alueita ruvettiin kutsumaan "puukaupungeiksi". Tämän he tulkitsevat Bontan mallin valossa merkitsevän

1 Bontan yhdeksän vaihetta ovat blindness, pre-canonical responses, canonical interpretation, authoritative interpretation, classification, dissemination, silence or oblivion, reinterpretation sekä text analysis. 
nimenomaan puukaupunki-käsitteen muutosta. Toiseksi he katsovat myös tiiviin ja matalan idean tulleen vanhoista puukaupungeista: "One outcome was the so-called 'dense low-rise' trend in urban planning and building design. Inspiration was looked for in the historical wooden towns, whose density had until then been seen as a defect - -". Historiallisten kaupunkien tiiviys oli aiemmin katsottu haitaksi, mutta nyt ne olisivat siis tarjonneet mallin myös uudelle puuarkkitehtuurille. (Kalakoski ym., 2020, s. 800-801, lainaus s. 800.)

Kumpikin näistä näkökohdista esittää uuden puurakentamisen tulkitsevan varsin suoraan historiallista puukaupunkiperinnettä. Perehtyminen 1990-200o-luvun vaihteen kehittämishankkeisiin osoittaa kuitenkin tällaisen käsityksen liian yksinkertaistavaksi. Puukaupunki-nimityksen omaksuminen uuteen asiayhteyteen ei vielä tarkoita alkuperäisen käsitteen 'pohjoismainen puukaupunki' muuttuneen. Pikemminkin kyse oli sen venyttämisestä tai sivumerkityksestä, jonka voima perustui alkuperäiseen käsitteeseen. Tiivis ja matala puolestaan, vaikka vaikuttikin merkittävästi uuteen puurakentamiseen, pohjautui puurakentamista laajempiin lähtökohtiin.

Itse asiassa uusi puurakentaminen sovelsi puukaupungin nimitystä hyvin vapaasti. Avaimena on ymmärtää 1990-luvulla virinneen uuden puurakentamisen pyrkineen alueellisiin toteutuksiin. Silloin ei ollut olennaista varsinaisesti määritellä tai pyrkiä kiteyttämään uudenlaista puukaupungin käsitettä, vaan tarkastella puurakentamisen uusia mahdollisuuksia tutkimushankkeissa ja käytännössä. Tällaisen ennakkoluulottoman lähestymistavan kääntöpuolena oli modernin puurakentamisen kunnioittava suhde historiallisen puukaupungin määrittelyyn. Erityisen hyvin tämä kunnioitus ilmeni täydennysrakentamisessa. Kalakoski ja muut mainitsevat täydentämisen aihepiirin, mutta eivät tarkastele syvemmin sen merkitystä uudelle puurakentamiselle (2020, s. 799-80o).

Vuonna 1997 alkoi uutta puurakentamista tutkinut Moderni puukaupunki -hanke. Täydennysrakentaminen tuli esiin heti sen ensimmäisen, kaksivuotisen vaiheen lyhyehkössä raportissa. Siinä mainitaan vanhoissa puukaupungeissa havaituista aukkopaikoista, joita koskevat yhteydenotot kuntiin eivät kuitenkaan johtaneet merkittäviin jatkotoimiin, vaikka joissakin niistä katsottiinkin olevan edellytyksiä "puukaupunkirakenteen eheyttämishankkeisiin modernin puurakentamisen keinoin". (Karjalainen, suikkari \& Koiso-Kanttila, 1999, s. 35) Myöhemmässä, vuoden 2002 raportissa varsinkin Kati Jokelaisen kirjoittama luku 3, "Esimerkkejä täydennysrakentamisesta vanhaan puumiljööseen", tarkastelee täydennysrakentamista puukaupunkiperinteen valossa. Yhtenäisen miljöön ajatus korostuu: "Täydentäminen on kokonaiseksi tekemistä. Uuden rakennuksen tulee olla kuin palapelin puuttuva pala. Ympäröivät palaset rajoittavat uuden muotoa, värejä, suhteita... Samalla ne antavat vinkkejä, millainen täydentävä palanen 
voisi olla." Alaotsake "Tarina" korostaa erilaisten selvitysten tarvetta, "Suojelu" puolestaan täydennysrakentamista osana koko ympäristön rakennussuojelua. Kirjoittajan mukaan rajut kontrastit vanhaan ympäristöön nähden ovat mahdollisia mutta harvoin tarpeen, ja pahin virhe on sijoittaa aukkokohtaan mittakaavaltaan liian poikkeava rakennus. (Jokelainen, 20ozb.)

Tällainen vanhaan sovittamisen ongelma ei koskenut täysin uusia puurakentamisalueita, muuten kuin korkeintaan laajemmassa kaupungin kontekstissa. Uuden puurakentamisen alueellisuus alkoi korostua juuri 199o-luvun kehityshankkeissa. Näissä yhteyksissä pohdittavaksi tuli myös modernin puurakennuksen vanhasta poikkeava arkkitehtoninen ilmaisu. Aihetta käsiteltiin edellä mainitussa Moderni puukaupunki -hankkeen julkaisussa. Kati Jokelainen kirjoitti luvun "199o-luvun puujulkisivujen estetiikasta". Jouni Koiso-Kanttilalta voi mainita kirjoitukset "Suomalainen moderni puuarkkitehtuuri" ja "Uuden puurakentamisen haasteet". (Jokelainen, 2002a; Koiso-Kanttila, 2002a, 2002b.) Arkkitehtien kasvanut tietoisuus puurakentamisen perinteestä merkitsi sekä sidosta vanhaan että pyrkimystä irrottautua siitä, ja molemmat pyrkimykset ilmenivät Moderni puukaupunki -hankkeesta. Täydennysrakentamisen ja uuden alueellisen puurakentamisen kysymykset voi siksi kuvata rinnakkaisiksi: ne olivat yhtä aikaa olemassa mutta eri tavoilla suhteessa puurakentamisen perintöön. Vastaavasti myös puukaupungin käsitteen voi katsoa merkitsevän eri asioita näissä kahdessa tilanteessa: yhtäältä vanhaa, tunnustettua ja jopa kanonisoitua, toisaalta uutta ja vielä asemaansa hakevaa.

Edellä kuvatuista ongelmista huolimatta Kalakosken ja muiden kirjoittajien artikkeli osoittaa yleisen vahvan yhteyden uuden puurakentamisen ja historiallisen puukaupungin välillä. Tämä yhteys on merkityksellinen ja saa vahvistusta myös Moderni puukaupunki -hankkeen yhtenä tuloksena julkaistusta RT-ohjetiedostosta. Siinä esitettiin suosituksia kaupunkimaisen puutaloalueen suunnitteluun ja todettiin tavoitteena olleen "ottaa oppia vanhasta puurakentamisen perinteestämme, uudistaa sitä nykypäivän vaatimusten mukaisesti sekä hyödyntää puurakentamisen uusinta tutkimustietoa". Lisäksi mainittiin esimerkkikohteiden edustavan valtakunnallisen Tiivis ja matala -projektin tavoitteita. (Rakennustietosäätiö RTS, 2002.)

\section{Tiivis ja matala}

Moderni puukaupunki -hankkeesta alkaen uusi puurakentaminen sai vaikutteita myös tiiviin ja matalan kaupunkirakentamisen edistämisestä. Kyseessä ei ole alkujaan tarkkarajainen käsite vaan pikemminkin suuntaus, jota on tulkittu vaihtelevasti ja joka juuri 1990-luvun lopulla alkoi kiinnostaa kaupunkien kaavoituksen yhtenä vaihtoehtona. 
Rakennusneuvos, arkkitehti Olli Lehtovuori (puhelinkeskustelu 20.5.2021) palauttaa tiiviin ja matalan lähtökohdat tanskalaiseen tæt-lav-rakentamiseen, joka syntyi vastareaktioksi kerrostalorakentamiselle jo 196o-luvun lopulla, ja kertoo vaikuttaneensa siihen, että tiiviin ja matalan periaatteita sovellettiin Suomessa SAFAn vuosien 1971-1972 Asuntoreformikilpailussa. Pirjo Sanaksenaho (2017, s. 268-269) puolestaan mainitsee pientaloasumista käsittelevässä väitöstyössään suomalaiset 1960-1970-lukujen taitteen lehtikirjoitukset, joissa tiivis ja matala rakentaminen käsitettiin samalla tavalla kerrostalorakentamisen vaihtoehdoksi.

Vuonna 1998 Lehtovuori laati Asu ja rakenna -lehden numeroihin 3-6 sarjan kirjoituksia, jotka pohtivat kaupunkimaisen pientaloasumisen mahdollisuuksia vaihtoehtona kerrostaloasumiselle. Kirjoitukset sivusivat myös puurakentamista. Niistä ensimmäinen (Lehtovuori, 1998a) tarkasteli asumisen typomorfologisia näkökohtia ja asumisratkaisujen monipuolistamista, kuten liian väljiksi osoittautuneiden jälleenrakennuskauden omakotialueiden ja toisaalta tiiviiden kerrostaloalueiden väliin jääviä vaihtoehtoja. Lehtovuoren asuma (sanoissa asumatyyppi, asumatypologia ja asumamorfologia) oli kokoava käsite asunnolle, asuinympäristölle, asuinrakennusryhmälle ja asuma-alueelle. Lehtovuori katsoi asuinrakennustyyppejä koskevien ratkaisujen olevan kaavoituksen ja varsinaisen talosuunnittelun välimaastossa. Toisen kirjoituksen (Lehtovuori, 1998b) aiheena olikin kaavoituksen suuri vaikutus talotyypin valintaan ja liian yksioikoinen jako kerros- ja pientaloasutukseen. Lehtovuoren mukaan oli esimerkiksi epäoleellista, ovatko 2-3-kerroksiset asuinrakennukset kerrosvai pientaloja.

Kolmas kirjoitus (Lehtovuori, 1998c) esitti kaupunkiomakotitalon "puoliurbaanin omakotireformin" vaihtoehdoksi kerrostaloille, rivitaloille ja suurten tonttien omakotitaloille. Yhtenä esimerkkinä oli 300 neliömetrin tontille tarkoitettu kilpailuehdotus "Kaavaräätälin jätepalat", jonka suunnitteluun Olli Lehtovuori oli itse osallistunut. Hän viittasi myös rintamamiestaloja edeltäneeseen suomalaiseen puukaupunkiperinteeseen, johon kaupunkiomakotitalot voitiin rinnastaa juuri tonttien pienen koon ansiosta. Hänen mukaansa "'yhdenkoon' puupikkutalot pieninä 20-30 talon toteutuksina ovat lähes ainoa terve kilpailutekijä keskittyneelle asuntotuotantokoneistolle." Neljännessä kirjoituksessa Lehtovuori (1998d) pohti kerrostaloasumisen monipuolistamista ja asukkaiden vaikuttamismahdollisuuden lisäämistä. Ylimpien kerrosten terassiasunnot ja varsinaiset terassitalot, keskieurooppalaiset urbaanit poikittaisharjatalot ja "valopihatalot" olivat hänen ehdotuksiaan. Valopihatalossa pääosa asuntojen asuinhuoneista voisi avautua katettuun valopihaan. Lehtovuori ennakoi jo 1960-1970-lukujen vanhojen kerrostalolähiöiden kehittämistä tulevina vuosikymmeninä ja ehdotti yhdeksi keinoksi täydentävää uudisrakentamista, 
jolla voitaisiin monipuolistaa asuntokantaa. Hän katsoi lähiöiden monotonisuutensa vuoksi kestävän aiemmasta poikkeavia talotyyppejä, kuten matalia hissillisiä valopihataloja.

Samana vuonna 1998 ympäristöministeriö julkaisi aihepiiristä arkkitehti Maarit Kaipiaisen tutkimuksen Tiivis ja matala puurakentaminen (1998). Kuvailulehden mukaan ministeriö halusi tukea pienimittakaavaisen puurakentamisen uutta tulemista, mikä tarkoitti erityisesti 1-2-kerroksista asuinmiljöötä. Ministeriön yliarkkitehti Ritva-Liisa Salmen kirjoittaman esipuheen mukaan julkaisu liittyi nimenomaan Moderni puukaupunki -kehittämishankkeeseen. Vastaava suora yhteys puurakentamiseen ei kuitenkaan koskenut enää myöhempiä tässä käsiteltyjä tiiviin ja matalan julkaisuja.

Lehtovuoren tavoin Kaipiainen haki tiiviin ja matalan lähtökohtia tanskalaisten suunnittelijoiden 1960-1970-luvuilla korostamasta kaupunkimaisesta mallista. Esimerkit oli - muutaman tanskalaisen ja norjalaisen ohella - poimittu pääosin Helsingin ja pääkaupunkiseudun 1970-1980-lukujen rakentamisesta. Kirjoitusajankohdan puurakentamisesta mainittiin Tuomo Siitosen voittanut kilpailuehdotus Porvoonjoen länsirannalle: "Suunnitelman suurkorttelijaon mittakaava perustuu empire-korttelien rytmiin, mutta rakentamisen rakeisuus muistuttaa vanhan Porvoon rantakorttelien kampamaisuutta." (Kaipiainen, 1998, lainaus s. 18.) Kaipiainen kiinnitti siten huomiota ehdotuksen puurakentamisen perinnettä uudistaviin piirteisiin.

Ympäristöministeriö käynnisti erityisen Tiivis ja matala -nimisen projektin vuonna 2001. Tavoitteena oli vauhdittaa "uudenlaisten kaupunkimaisten pientaloyhdyskuntien suunnittelua ja toteutusta". Tiivis ja matala tarkoitti noin tuhannen neliömetrin tontilla olevan omakotitalon ja lähiökerrostalon välimuotoa. Ajatuksellisina lähtökohtina olivat $\mathrm{mm}$. puutarhakaupungin ihanteet, Yhdysvaltojen New Urbanism -liikkeen suunnitteluperiaatteet ja toiminnoltaan sekoittunut kaupunki tai pikkukaupunki. Tiiviin ja matalan toteuttaminen edellytti asuntotyyppien tarkastelua jo kaavoitusvaiheessa. (Korpivaara, 2007, s. 13, 15.) Hanketta johtaneen rakennusneuvos, arkkitehti Aila Korpivaaran mukaan (puhelinkeskustelu 21.5.2021) tämä rakennusten ja kaavoituksen välisen yhteyden korostus oli merkittävää. Rakennusmateriaaleihin ei pyritty ottamaan kantaa, mutta puurakentaminen sopi hyvin matalaa kaupunkirakentamista korostavan hankkeen piiriin. Hankkeen taustalla oli hallitusohjelma. Korpivaaran mukaan eri tahot, kuten ministeriö, Tekes, VTT, Puuinfo / Woodfocus oy ja yliopistot, tekivät 1990- ja 2000-lukujen vaihteessa paljon hankeyhteistyötä. Yleisesti ympäristöministeriö ei siten liittänyt tiiviin ja matalan edistämistä ainoastaan puurakentamiseen. 
Tämän vaiheen julkaisuja lukiessa on syytä erottaa 1990-luvun rakentamiseen mahdollisesti vaikuttaneet esikuvat (kuten tæt-lav) yleisemmistä tiiviin ja matalan historiallisista assosiaatioista. Jälkimmäisiä edustaa vuonna 2002 ilmestynyt Pekka Lahden esitutkimus Matala ja tiivis kaupunki, joka taustoitti aihepiiriä hyvin väljästi "kolmen suuren linjan" eli keskiaikaisen kaupungin, pohjoismaisen puukaupunkiperinteen ja englantilaisen puutarhakaupungin välityksellä. Mukaan oli otettu vaihtelevasti myös 1900-luvun esimerkkejä lähiörakentamista myöten. Lähtökohta historian tarkastelulle oli näissä esimerkeissä kaupunkirakenne ja tiiveys. Julkaisussa tarkasteltiin myös laskennallisesti rakennustehokkuuksia Helsingin seudulla ja osin historiallisissa kohteissa. (Lahti, 20o2.)

Tiiviin ja matalan määrittelivät varsin ytimekkäästi Rikhard Manninen ja Sari Puustinen tutkimuksessaan Tiivistä ja matalaa Helsingin seudulle, joka perustui 40 henkilön haastatteluun. Tässä katsannossa tiivis ja matala oli olennaisesti kaavoitusta, maankäyttöä ja ympäristön laatua koskeva periaate, jonka toteutus haastaisi suunnittelun instituutiot. Rakennustyyppeihin se suhtautui kuitenkin sallivasti. Yhteenvetona määritelmä kuului: "Tiivis ja matala alue on osoitettu ensisijaisesti asumiseen. Sen tonttitehokkuuden minimiarvo on o,3 ja kerrosluku enintään kolme. Asunnoista on yleensä uloskäynti suoraan omalle pihalle tai kadulle. Alueen suunnittelussa ja toteutuksessa pyritään kaupunkimaisuuteen ja ihmisläheisyyteen. Suunnittelun ensisijaisena tavoitteena on mahdollistaa asukkaille sosiaalisesti rikas ja hyvä elämänlaatu. Suunnittelussa ja toteutuksessa pyritään tiiviin rakenteen avulla kustannustehokkuuteen ja kestävään kehitykseen. Tiiviin ja matalan määritelmä ei ole sidottu tuotantotapaan, asuntojen hallintamuotoon, arkkitehtuuriin eikä talotyyppiin." (Manninen \& Puustinen, 2002, s. 23.)

Kirjoittajat löysivät haastatteluaineistosta tiiviin ja matalan tärkeimmiksi esikuviksi suomalaisen tai pohjoismaisen puurakentamisperinteen sekä etenkin anglosaksisten maiden tehdaskaupungit ja klassisen puutarhakaupunkimallin. Puurakentamista edustivat suomalainen empire sekä Rauman ja Porvoon puukaupunginosat, mutta myös toisen maailmansodan jälkeiset rintamamiestaloalueet väljyydestään huolimatta. (Manninen \& Puustinen, 2002, s. 18-21.) Kun lähtökohtana olivat haastattelut, nämä käsitykset saattoivat kuvastaa tiiviin ja matalan esikuvia myös 199o-luvun lopulla.

Tiiviin ja matalan katsottiin täyttävän useita tavoitteita. Nuorten lapsiperheiden arveltiin hakeutuvan pientaloihin osana laajempaa eurooppalaista ilmiötä. Se oli vastaus toiveisiin saada asua pientalossa tai pientalon ja kerrostalon välimuodossa. Koska ei haluttu loputtomasti leviäviä omakotimattoja eikä suunnittelemattomasti rakentuvaa haja-asutusta suurten kaupunkien 
reuna-alueille, oli kehitettävä vaihtoehtoisia tehokkaan maankäytön malleja. (Korpivaara, 2007, s. 13.) Julkaisuissa tavoiteltiin myös kohtuuhintaista asumista, ympäristön säästämistä, "ekotehokkuutta", yhdyskuntateknistä taloudellisuutta sekä eheämpää ja liikenteellisesti tehokkaampaa kaupunkirakennetta.

Tiiviin ja matalan periaatteet ja myös niiden sallivuus konkretisoituivat vuoden 1998 jälkeen aloitetuissa asuinaluehankkeissa. Aila Korpivaaran ja Jukka Alapihan toimittama Tiivis ja matala korttelirakenne esitteli vuonna 2005 kymmenen tällaista hanketta. Joukkoon kuului asemakaavaltaan, talotyypeiltään ja materiaaleiltaan vaihtelevia kokonaisuuksia ja erilaisten ympäristöjen suunnittelu- ja toteutusratkaisuja, jotka tiiviin ja matalan käsite kokosi ikään kuin vertailtaviksi. Esimerkkien väliset erot koskivat muun muassa sijaintia, liikenneyhteyksiä, palveluita, virkistysmahdollisuuksia, alueen luonnetta ja identiteettiä, korttelirakennetta ja korttelin muotoa, julkisia ja yksityisiä ulkotiloja, pysäköintiä, rakentamistehokkuutta, talotyyppiä sekä rakennuksen suhdetta pihaan ja katuun (Korpivara \& Alapiha, 2005). Tulevina vuosina tiivistä ja matalaa rikastettiin edelleen. Vuonna 2006 ilmestyi julkaisu Alankomaiden tiiviistä ja matalasta rakentamisesta sekä Helsingin kaupungin tutkimus englantilaisen townhousen soveltamisesta. Jälkimmäistä tutkittiin myös vuonna 2007 alkaneessa Yhdyskuntasuunnittelun tutkimus- ja koulutuskeskuksen URBA-hankkeessa. Kyseessä oli yksi hankkeen alussa tarkasteltavaksi otetuista kahdestatoista "asumisen konseptista", esikuvana keskieurooppalainen ja Mannisen ja Puustisen mainitsema englantilainen kaupunkirakentaminen. (Straver-Nevalainen, 2006; Manninen \& Holopainen, 2006; Mälkki, 2010. Norvasuo, 2008.)

\section{Puurakentaminen tiiviin ja matalan sovelluksena}

Puurakentamista alettiin edistää kehittämisohjelmin 199o-luvun alkupuolella. Toiminnan lähtökohdat olivat jo 1980-luvun jälkipuoliskolla sahateollisuuden ja puutuotekaupan perustamassa yhteistyöryhmässä, joka päätti ohjata tulovirroista pienen osuuden puunkäytön ja puurakentamisen kehittämiseen. Kehittämistyö alkoi vuosina 1988-1989 nk. luottamusneuvoston puitteissa ja siirtyi sieltä vuonna 1992 perustettuun Puuinfo oy:hyn. Luottamusneuvostoa johtaneesta Pertti Hämäläisestä tuli samalla Puuinfon toimitusjohtaja. Uuden organisaation tehtäviin sisältyi koulutus- ja kehitystyö, ja se osallistui käynnistettäviin teknologiaohjelmiin. (P. Hämäläinen, puhelinkeskustelu 28.5.2021.) Alkuvaiheen ohjelmista voi mainita TEKESin Puun mekaanisen teknologian ja Puulevyteknologian ohjelmat vuosina 1992-1997 sekä Puurakentamisen teknologiaohjelman vuosina 1995-1998. Viimeksi mainittu hanke käynnisti myös puukerrostalojen kehittämistyön. Ensimmäiset puukerrostalot rakennettiin poikkeusluvin Ylöjär- 
velle, Helsingin Viikkiin, Ouluun, Tuusulaan ja Raisioon vuosina 1996-1997 (Peura, Grundahl, Berg \& Pihlajanmaa, 2000, s. 1 ja muualla; P. Hämäläinen, puhelinkeskustelu 28.5.2021; Karjalainen, 2002, s. 105.).

Puurakentamisen edistäminen ei siis tässä vaiheessa kohdistunut matalaan "puukaupunkiin" vaan nimenomaan kerrostaloihin. Niihin tähtäsi aluksi myös Oulun yliopistosta alkunsa saanut Moderni puukaupunki -hanke. Se käynnistyi vuonna 1997, ensin TEKESin rahoituksella, ja jatkui sen jälkeen sekä tutkimusjaksoina että puurakentamisen edistämistyönä aina vuoteen 2013. Varsin pian huomio kuitenkin kohdistui matalaan alueelliseen puurakentamiseen. Tätä on selitetty kahdella tavalla: ensinnäkin puukerrostalojen kehittämisen kohtaamilla vaikeuksilla ja toisaalta matalampaan rakentamiseen kohdistuneella kysynnällä. Viikin hankkeessa projektipäällikkönä olleen Pekka Nurron mukaan (puhelinkeskustelu 20.5.2021) panostus kerrostalojen kehittämiseen ei johtanut toivottuun puukerrostalorakentamisen kasvuun. Tällöin ryhdyttiin matalamman puurakentamisen edistämiseen. Pertti Hämäläinen (puhelinkeskustelu 28.5.2021) katsoo pääsyyksi sen, etteivät rakennusliikkeet onnistuneet kehittämään hinnaltaan riittävän kilpailukykyistä tuotetta, jolloin niiden mielenkiinto sammui. Moderni puukaupunki -hankkeen projektipäällikkönä toiminut Markku Karjalainen puolestaan muistaa (puhelinkeskustelu 26.5.2021), että hankkeelle tuli pian eri puolelta Suomea toiveita matalamman alueellisen rakentamisen edistämisestä. Tällöin aloitettiin myös yhteistyö ympäristöministeriön kanssa.

Vaikka siis puukaupunkiperinteestä oppiminen sisältyi Moderni puukaupunki -hankkeen miljöökorostukseen (Karjalainen, 2002, s. 12), kannustin keskittyä matalaan alueellisen puurakentamiseen syntyi toista tietä. Tiivis ja matala puolestaan ikään kuin liitettiin samaan yhteyteen ympäristöministeriön aloitteesta. Se näyttää tarjonneen ajankohtaisen tavan liittää puurakentaminen kaupunkisuunnitteluun muiden rakennusmateriaalien rinnalla.

Vuoden 2002 RT-ohjetiedostossa "Tiiviin puutaloalueen suunnittelu" tiiviin ja matalan esimerkkiratkaisuina olivat Oulun Puu-Linnanmaa, Porvoon Länsirannan puutaloalue, Tuusulan Nummenharjun Huminakujan puukorttelit sekä Mikkelin Orijärven puutaloalue (Rakennustietosäätiö RTS, 20o2). Mainittuun Korpivaaran ja Alapihan julkaisuun (2005) lukeutui myös puurakentamisalueita. Kolmea niistä oli esitelty vuonna 2004 Puu-lehdessä: Espoon Friisilän Aurinkorinteen pientaloja, Porvoon Länsirannan puukorttelia ja Lehtovuoren asuinaluetta Helsingin Konalassa. Vuoden 2001 tontinluovutuskilpailun pohjalta suunniteltu Lehtovuoren alue koostui kolmesta tiiviistä "kylämäisestä" korttelikokonaisuudesta. Rakennusten rungot olivat osin betonia mutta julkisivut puuta. Alueen valmistuttua vuonna 2005 arkkitehti Maarit Kaipiainen katsoi Helsingin Sanomien uutisessa sen tarjoavan mallia 2000-luvun puukaupungille. Aurin- 
korinteen pientaloalue jakoi yhdessä Laajasalon kirkon kanssa vuoden 2004 puupalkinnon. ("Rakennukset", 2004; Salmela, 2005.)

Vuonna 2007 ilmestynyt teos Kotina puinen kaupunkikylä jatkoi suoraan Moderni puukaupunki -hankkeen teemoja. Teoksessa esiteltiin 21 alue-esimerkkiä, joihin kuuluivat myös Helsingin Lehtovuori ja Myllypuro, Porvoon Länsiranta sekä Turun Linnanfältti. Teoksen artikkeleista voi mainita Jouni Koiso-Kanttilan "Puukerrostaloista puisiin asuinmiljöisiin", Aila Korpivaaran jo edellä viitatun "Monipuolisempaa asuinympäristöä", Pekka Heikkisen "Puukaupunkiperinteestä nykyaikaan", Markku Karjalaisen ja Riku Patokosken "Kuinka hyvä Moderni puukaupunki syntyy", Matti Karhulan "Käytännön asuntopolitiikkaa - Oma talo Oulussa" sekä Risto Suikkarin ja Jarkko Salovaaran "Asukaspalaute opettaa”. (Heikkinen, 2007; Karjalainen \& Patokoski, 2007; Koiso-Kanttila, 2007; Korpivaara, 2007; Suikkari \& Salovaara, 2007.)

Tutkimusjulkaisuista voi erottaa kaksi näkökulmaa: ensinnäkin puurakentamisen luontevat käyttötavat ja toiseksi puurakentamisen alueellisen toteutuksen. Ensimmäistä edustavat Jouni Koiso-Kanttilan pohdiskelut kerrostalorakentamisesta Moderni puukaupunki -hankkeessa. Hän kirjoitti puukerrostaloista vaihtoehtona perinteiselle betoniselle kerrostalorakentamiselle ja korosti puun mahdollisuuksia julkisivumateriaalina. Lisäksi puu salli betonirakentamista runsaamman massoittelun. Siinä mielessä rakennusmateriaalin vaihdossa oli kyse enemmästä kuin vain julkisivuista tai viimeistelystä, sillä puurakentamisen erityisenä teknisenä ja taloudellisena etuna betoniin nähden oli mahdollisuus rakentaa pienimittakaavaisesti ja näin toteuttaa myös toive saada asua pientalossa. Nimenomaan puiset pienkerrostalot tarjoaisivat pientalomaisia, ihmisen mittakaavan mukaisia asumisratkaisuja. (Koiso-Kanttila, 20o2b, s. 48-51.)

Alueellinen puumiljöön korostus puolestaan ilmenee Koiso-Kanttilan artikkelista teoksessa Kotina puinen kaupunkikylä. Hän liitti uuden puurakentamisen vanhoihin puukaupunkeihin todeten: "-- suomalaiset pitävät puuta asuinrakentamiseen parhaiten soveltuvana rakennusmateriaalina ja -- puurakennusten sekä itse puumateriaalin kauneutta arvostetaan - - perinteisiä puukaupunkeja ei arvosteta ainoastaan siksi, että ne ovat vanhoja, vaan myös siksi että ne ovat puisia." Toisaalta hän päätyi, lähtien ajatuksellisesti puukerrostaloista, kannattamaan muutaman kymmenen rakennuksen kylämäisiä asuinmiljöitä keskustojen ulkopuolella. Siellä puukerrostalot eivät enää olisi järkevä vaihtoehto. (Koiso-Kanttila, 2007, s. 7-8.)

Samassa teoksessa Pekka Heikkinen (2007) konkretisoi tiiviin ja matalan puukaupungin toteamalla sen rakentuvan kaksi- ja kolmikerroksisista puutaloista. Tavoiteltu tonttitehokkuus olisi o,4-0,5. Jälkimmäisen luvun soveltaminen "johtaa uudenlaiseen ympäristöön, jossa asuntoa, pihaa ja asukkaan yksityistä reviiriä pitää tarkastella aivan uudella tavalla. Lähtökohta on, että 
luodaan asuinympäristöä, jota ei aiemmin ole nähty". Omaleimaisen identiteetin tavoittelu olikin Markku Karjalaisen ja Riku Patokosken (2007, s.26) mukaan keino erottautua asuntotuotannon kilpailijoista. Mainittu tonttitehokkuus vastasi tuolloin toteutettujen tiiviiden ja matalien kohteiden tehokkuuksia (Korpivaara \& Alapiha, 2005). Matti Karhula (2007, s. 38-39) esitteli omassa artikkelissaan Oulun asemakaavoituksen laatimia mallitalojen julkisivusuunnitelmia, jotka oli tarkoitettu yksilöllisten suunnitelmien pohjaksi tavoitteena rakentaa 50 omakotitaloa 600 neliömetrin tonteille.

Historiallisesta puukaupungista poiketen tiivis ja matala puurakentaminen näyttäytyi keskustarakentamisen ulkopuolelle tarkoitettuna mallina. Syyt saattoivat olla kaavoituksellisia, koska esikaupungeissa oli tilaa vanhojen puumiljöiden lailla yhtenäisille alueille. Esimerkkejä tällaisista uusista alueista olivat kylämäiset Puu-Myllypuro ja Lehtovuori Helsingin esikaupunkivyöhykkeellä. Nimenomaan tiiviys erotti uudet puurakentamisalueet modernin kauden väljistä esikaupunkien puurakennusalueista, kuten teollisuuden tehtaiden työväestölle rakentamista asuinalueista ja jälleenrakennuskauden tyyppitaloalueista. Sen lisäksi tiiviin ja matalan periaate salli vaihtelevan rakennuskorkeuden. Tämä ilmeni sekä Moderni puukaupunki -hankkeesta että Kotina puinen kaupunkikylä -teoksesta. Tässä yhteydessä voi muistaa Olli Lehtovuoren ajatuksen siitä, että 2-3-kerroksisessa rakentamisessa pientalon ja pienkerrostalon erottelu ei ollut olennainen.

Jälleenrakennuskauden tyyppitaloalueita tutkinut Kirsi Heininen-Blomstedt (2013, s. 211-215) viittaa esikaupunkiympäristön marginaalisuuteen suhteessa kantakaupunkiin 1900-luvun alkupuolella, kun kaupunkeja ympäröivät kylät muuttuivat omakotialueiksi. Hän katsoo vastaavan ilmiön koskeneen myös jälleenrakennuskauden puutaloalueita:"Jälleenrakennusaika oli siirtymävaihetta maalaisen ja kaupungistuneen välissä. Jälleenrakennuskauden alueilla 'maaseutu' on ollut läsnä elämäntavoissa ja miljöössä. Suomalaisuuden agraarit juuret ovat nolostuttavan lähellä.” Tulkinnassaan hän erottaa asumismuodon ja miljöön tyyppitalojen arkkitehtuurista: edellisiä määrittelevät avoin rakennustapa ja omatonttisuus, jälkimmäinen puolestaan voidaan katsoa 1920-luvun klassismin tyyppipiirustusten jatkokehittelyksi. Laura Kolben (2005) mukaan esikaupunki syntyi 1900-luvun alussa tiiviille kaupungille hallinnollisesti, kulttuurisesti ja poliittisesti vastakkaisena ilmiönä ja sulautettiin vasta myöhemmin osaksi kaupunkikokonaisuutta. Huvilaesikaupungin vapaa, orgaaninen muoto puolestaan oli vastakkainen vanhan kaupungin säännöllisyyden korostukselle.

Tiiviin ja matalan puurakentamisen suhde kaupunkiin samoin kuin esikaupunkiin oli siis monitulkintainen. Sen saattoi assosioida vanhaan puukaupunkiin, joka satoja vuosia olennaisesti määritteli suomalaista kaupunkia 
ydinalueineen ja jonka piirissä esimerkiksi otettiin käyttöön ensimmäiset ruutukaavat. Nykyisen kaupunkisuunnittelun näkökulmasta taas kyse oli ensi sijassa esikaupunkialueista. Tiiviin ja matalan kaavoitusratkaisut mahdollistivat laajan kirjon erilaisia toteutuksia. Niiden monimuotoisuus ei ollut vain periaatteellista, vaan ilmeni myös jo toteutetuista puurakentamisen alueista.

\section{Kohti korkeampaa}

Tultaessa 2010-luvulle omakotirakentamisen aloitukset alkoivat vähentyä, ja vuodesta 2015 kerrostalorakentaminen alkoi voimakkaasti lisääntyä. Rakennusteollisuus RT:n mukaan jälkimmäistä selitti kaupungistuminen sekä yhden ja kahden hengen kotitalouksien lisääntyminen ("Asuntokanta. Asuntoaloitukset talotyypeittäin", 2019). Kaupunkiseutujen kasvua oli ilmiönä jatkunut jo 1990-luvulta (esimerkiksi Rehunen, Ristimäki, Strandell, Tiitu \& Helminen, 2018, s. 17). Myös suhtautuminen kaupunkiasumiseen näytti muuttuvan. Tiiviin ja matalan oli arveltu toteuttavan lapsiperheiden toivetta asua omakotitalossa. Kuitenkin nettomuuton avulla tarkasteltuna kaupunkikeskustoista tuli yhä selvemmin myös lapsiperheiden suosimia ympäristöjä. Helsingissä kantakaupungin o-6-vuotiaiden lasten suhteellinen osuus oli alkanut kasvaa esikaupunkeja nopeammin jo vuonna 2004 (Mustonen \& Lindblom, 2016). Ilmiötä tutkineen Johanna Liliuksen (2019) mukaan kerrostalovaltaisen keskusta-asumisen suosioon oli vaihtelevia syitä, kuten vanhasta rakennuskannasta pitäminen, sosiaaliset syyt, tarjolla olevat palvelut tai ulkomailla asumisesta kertyneet kokemukset.

Helsingissä uusi yleiskaava asettui myös korkeamman ja "keskustamaisemman" rakentamisen kannalle. Edellinen, vuoden 2002 yleiskaava oli korostanut esikaupunkien tiivistämistä. Vuoden 2016 yleiskaavassa huomio kohdistettiin keskusta-alueisiin. Vaikka yhdessä pohjustavassa selvityksessä esiintyi edelleen tiiviin ja matalan kuvastoa (Helsingin yleiskaava. Kohti urbaanimpaa Helsinkiä, 2013), kaupunkikulttuurin korostaminen, keskustaan johtavien pääväylien "bulevardisointi" ja esikaupungin "keskuksien" muuttaminen "keskustoiksi" implikoivat kerrostalorakentamista (Helsingin yleiskaava. Kaupunkikaava -Helsingin uusi yleiskaava. Visio 2050, 2013). Tiivistä ja matalaa ei kuitenkaan ole täysin unohdettu. Helsingin vuoden 2020 asuntopoliittisena tavoitteena mainitaan edelleen kaupunkimaisen pientalorakentamisen kehittäminen ja tarjonta hallitsevan kerrostalotuotannon ohella, samalla kun tavoitteena on tiivis kaupunkirakenne (Helsingin kaupunki, Kaupunginkanslia, ei pvm., s. 64).

Puukerrostalojen teknologinen kehitystyö ja palomääräysten uudistaminen mahdollistivat puun käytön muuttuneessa kaavoitustilanteessa. Alkuvaiheessa vuodesta 1995 eteenpäin rakentaminen oli vielä perustunut poikkeuslupiin. Vasta vuosina 1997-2011 palomääräyksiin tehtyjen muutosten jälkeen tuli mahdolliseksi rakentaa 3-8-kerroksisia puukerrostaloja ilman poikkeuslu- 
pamenettelyä. Kannustimeksi on katsottu myös Ruotsista saadut myönteiset kokemukset ja metsäyhtiöiden kiinnostus rakentamisen teollistamiseen. (Tolppanen ym., 2013, s. 17-19.) Puukerrostalojen valmistumistahti alkoikin jälleen kiihtyä vuodesta 2011 (Puuinfo, 2019).

Viimeaikainen kehittämistyö on pitkälti kohdistunut teolliseen valmistukseen. Siinä hyödynnetään runsaasti massiivipuutuotteita kuten CLT-massiivipuulevyä (cross-laminated timber), LVL-viilupuuta (laminated veneer lumber) ja kokonaisia tilaelementtejä. (Moilanen, 2019; Sipiläinen, 2020, s. 12, 41) Puukerrostalojen teollinen tuotanto on ymmärrettävä tavoite, kun puurakentaminen hakee tasavertaista asemaa betonirakentamisen rinnalla. Betonirakentamisen ratkaisut ovat kypsyneet vuosikymmeniä sitten, ja sen pitkälle hiottua tuotantojärjestelmää on vaikea haastaa.

Talonrakennus alkoi vahvasti teollistua jo 1950-luvulla, ja 1960-luku merkitsi elementtirakentamisen läpimurtoa. "Betonielementtisysteemi" eli BESjärjestelmä luotiin vuosina 1968-1970 ja sille jatkoksi Runko-BES 1980-luvulla. Lähiörakentamiseen omaksutulla järjestelmäajattelulla oli vaikutuksia kaavoitukseen, ja se vaikutti myös rakennusliikkeiden syntyyn ja organisoitumiseen. (Elementtirakentamisen historia, [sd]; Hankonen, 1994, s. 139-223.)

Kaavoitus katsotaan kaupungeissa keskeiseksi puurakentamisen edistämisen keinoksi. Vuonna 2020 julkaistiin keskeisimmistä kaavoittamiseen liittyvistä näkökohdista opas, joka keskittyy erityisesti puukerrostaloihin. Aihealueita ovat muun muassa tonttivarannosta huolehtiminen ja tonttien osoittaminen puurakentamiseen, kaavamerkinnät ja määräykset sekä määräysten sisältö ja yhteensovittaminen. Oppaassa esitellään myös hiilijalanjäljen laskennan perusteluja sekä puurakennejärjestelmien ominaispiirteitä ja käyttöä eri kerrostalotyypeissä. Kaupunkirakennetta koskeva sisältö on melko yleispiirteistä ja käsittelee lähinnä sijaintia, tonttijakoa ja pysäköintiä. Tätä puolta havainnollistavat kuitenkin monet esimerkit, joihin lukeutuu myös Turun Linnanfältti. (Puurakentamisen edistämisen ja ohjauksen keinot kaavoituksessa -opas, 2020.)

Keskustoissa rakennustehokkuuden lisääminen merkitsee tyypillisesti tiivistämistä yksittäisillä rakennuskohteilla. Tällaiseen rakentamiseen puukerrostalot ovat soveltuneet hyvin. Suuri osa suunnitteillakin olevista puukerrostalokohteista on yksittäisiä tai muutaman rakennuksen kokonaisuuksia (Ympäristöministeriö ja Puuinfo, 2019). Toistaiseksi puukerrostaloilla on luotu melko vähän tiivistä korttelirakennetta. Linnanfältti on kuitenkin kiinnostava tulkinta tiiviiseen korttelirakenteeseen luodusta yhtenäisestä kerrostalokaupunginosasta. Se on myös yksi pisimpään jatkuneista alueellisista puurakentamishankkeista. Turun kaupunki ilmoitti alueen puurakentamisen valtakunnalliseksi pilottihankkeeksi jo vuonna 2004. Vaikka uusia puukerrostaloja oli jo ehditty rakentaa 
siihen mennessä, Linnanfältti on ollut monella tavalla siirtymävaiheen hanke. Sen aikana osalla alueesta toteutui muutos tiiviistä ja matalasta korkeampaan rakentamiseen, ja samoin tarkasteltiin sekä uuden puurakentamisen suhdetta rakennusperintöön että puukerrostalojen toteutusta keskustamaisella ruutukaavaan liittyvällä alueella. Linnanfältin vuonna 2014 voimaan tulleessa asemakaavassa voitiin myös määrätä puu rakennusten runko- ja julkisivumateriaaliksi. (Tyni-Kylliö \& Rajala, 2019.)

Näin Linnanfältin hanke havainnollistaa kaavoituksen käyttöä puurakentamisen ohjauksessa, mutta siinä ilmenee myös teknologian vaikutus puukerrostalon ulkonäköön. Rakennustapa, monikerroksisuus ja nykyrakentamisen edellyttämät pysäköintikannet vaikuttavat olennaisesti uuden puukaupungin ilmeeseen ja erottavat sen historiallisesta kaupungista. Tilaelementein toteutettuna rakennusten volyymit ja sileät julkisivut poikkeavat vanhasta puurakentamisesta.

\section{Johtopäätökset}

Puurakentamisen edistäminen on edennyt näennäisen lineaarisesti matalasta puurakentamisesta kohti korkeampaa puukerrostalorakentamista. Tarkemmin katsottuna tapahtumat kuitenkin etenivät monen tekijän yhteisvaikutuksena. Puurakentamisen keskittymistä matalaan rakentamiseen yli kymmenen vuoden ajan (noin vuosina 1997-2010) selittävät pitkälti edellä kuvatut muutaman avaintahon (Puuinfo, Oulun yliopisto ja ympäristöministeriö) käynnistämät projektiketjut. Tärkeitä projekteja olivat erityisesti Moderni puukaupunki sekä Tiivis ja matala. Varsinaisena sysäyksenä ensimmäisille hankkeille näyttää kuitenkin olleen ensimmäisten kerrostalohakkeiden huono menestys yhdistettynä puurakentamisen edistämisen tavoitteisiin. Näihin hankkeisiin ei kenties olisi yhtä helposti lähdetty, jos puukerrostalojen kehitystyö olisi lähtenyt vauhtiin jo 1990-luvulla.

Historiallisen puukaupungin saama huomio toimi näiden hankkeiden luontevana taustana. Suunnittelevien arkkitehtien tietoisuuteen puukaupungit olivat tulleet jo 1970-1980-luvuilla, ja hankkeiden alkaessa pohjoismaisen puukaupungin käsite oli jo vakiintunut. Vanhojen puumiljöiden täydennysrakentamista koskenut keskustelu oli edelleen näkyvissä, vaikka puurakentaminen alkoi jo suuntautua kohti kasvavan kaupungin ongelmia. Historiatietoisuus saattoi osin kanavoitua matalaan puurakentamiseen myös kuntien Moderni puukaupunki -hankkeelle esittämien toiveiden välityksellä. Alueellinen matala puurakentaminen, tiivis ja matala sekä sen taustalla vallinnut huoli yhdyskuntarakenteen hajautumisesta sopivat sisällöllisesti yhteen. Tuloksen voi kiteyttää hieman abstraktiin uuden puukaupungin käsitteeseen. Kun huomio 
kiinnittyi matalan puurakentamisen edistämishankkeissa kokonaisiin esikaupunkialueisiin ja kylämäisiin yhdyskuntiin, puurakentamisessa ei enää tarvinnut ottaa huomioon vanhaan ympäristöön sovittamista. Uusia alueita voitiin ruveta suunnittelemaan puhtaalta pöydältä.

Varsinkin eri toimijoiden yhteistyön näkökulmasta edellä kuvatun prosessin voi hahmottaa myös polkuriippuvuutena, jota edistivät useat samanaikaisesti vallinneet seikat. Polkuriippuvuuden käsite on hyödyllinen, koska se ei edellytä jyrkkiä katkoksia yksittäisten aiheiden edistämisessä vaan hahmottaa kehityksen suuntia laajempien muutosten kautta. Hannu Ruonavaara (2006, s. 57) on James Mahoney'a (2000, s. 507) siteeraten määritellyt polkuriippuviksi prosessit, "joissa kontingentit tapahtumat panevat alkuun institutionaalisia rakenteita tai tapahtumaketjuja, joilla on deterministisiä ominaisuuksia”. Tässä tapauksessa kontingenssia merkitsevä poikkeama oli alun puukerrostalohankkeiden odottamaton tai ainakin epätoivottu kariutuminen. Kun puurakentamisen edistämiselle kuitenkin oli resursseja ja kannustimia, tiivis ja matala puurakentaminen tarjosi uuden reitin eteenpäin. Tätä vaihtoehtoa ruokki myös kaupunkien rakentamistarve. Vaikka matalan alueellisen puurakentamisen kausi ei ollut kovin pitkä, sen piirissä syntynyt tutkimus- ja suunnitteluyhteistyö edusti monen toimijan yhdessä synnyttämää institutionaalista jatkuvuutta.

Hieman samankaltainen, joskin vaikeaselkoisempi useiden tekijöiden yhteisvaikutus näyttää muuttaneen puurakentamisen suuntaa 2010-luvulla. Vaikka puukerrostalojen kehittäminen oli periaatteessa jatkumoa jo 199o-luvulta, se ei aiemmin päässyt kunnolla vauhtiin. Uusia myötävaikuttavia tekijöitä olivat todennäköisesti 3-8-kerroksisiin puukerrostaloihin vaikuttaneet palomääräysten muutokset, rakentajien parantunut valmius hallita puurakentamista, kaupunkiseutujen kasvu ja kaupunkien kiinnostus kaupunkikeskustojen tiivistämiseen. Yhdessä ne suuntasivat huomiota täydennysrakentamiseen sellaisten yhtenäisten alueiden sijaan, joita matala alueellinen puurakentaminen oli tuottanut.

Kontrafaktuaalisesta näkökulmasta voi pohtia myös sitä vaihtoehtoa, että puukerrostalorakentaminen olisikin lähtenyt nousuun heti 1990-luvun puolivälissä. Tuolloin olisi saattanut korostua puun ominaispiirre nimenomaan rakennusteknisenä ja materiaalin valintana, kun taas itse tuote, kerrostalo, olisi säilyttänyt niitä ominaispiirteitä, joita pitkä betonirakentamisen kausi on tuottanut. Tällaisen kehityksen sijaan toteutunut matalan puurakentamisen edistäminen on todennäköisesti auttanut tunnistamaan puurakentamisen vaihtoehtoja. On voitu pohtia puurakentamisen suhdetta historialliseen puukaupunkiin, irtautua sitä koskeneista täydennysrakentamisen ajatusmalleista ja kokeilla uusien eheiden puumiljöiden mahdollisuuksia. Syntyi pien- ja rivi- 
taloasutuksen ja toisaalta kerrostalorakentamisen "puoliurbaani" välimuoto suomalaisena sovelluksena.

Kun puurakentaminen oli 190o-luvulla korostetusti pientalojen materiaali, uuden puurakentamisen eri muodot soveltuvat nyt yhdyskuntarakenteille keskustoista esikaupunkeihin. Verrattuna betonirakentamiseen puun erityinen mahdollisuus on monimuotoisuudessa ja rakentamisen eri mittakaavoihin sovittamisessa. Tiiviissä kaupunkikeskustojen katurakenteessa uudet puukerrostalot kuitenkin poikkeavat suomalaisesta ja pohjoismaisesta rakennusperinteestä. Turun Linnanfältti, yksi Moderni puukaupunki -hankkeen koerakentamisalueista, on tältä kannalta erityisen kiinnostava sovitus keskustaympäristöön.

Puun käytön perusteluissa hiilineutraaliutta ja luonnonvarojen kulutusta on alettu painottaa yhä enemmän. On mahdollista ehdottaa joitakin yhtäläisyyksiä nykytilanteen ja 1970-70-lukujen välillä. Tuolloista huomion kiinnittymistä puukaupunkien suojeluun saattoivat vahvistaa lähiörakentamisen huippukauden osuminen 1970-lukuun sekä toisaalta jo virinnyt lähiöiden kritiikki. Puumateriaalista tuli lähiörakentamiseen omaksutun betonin vastakohta, ja muodostui jännite puukaupunkien säilyttämisen ja uuden lähiörakentamisen edustamien kvaliteettien välille. Nyt puu- ja betonirakentamista tarkastellaan hiilitaseen ja ilmastonmuutoksen näkökulmasta. Voidaan siis jälleen tunnistaa vastakohtainen asetelma puu- ja betonirakentamisen välillä. Matalan puurakentamisen vaihe on kuitenkin osoittanut, että puu on rakennetun ympäristön kannalta paljon monitahoisempi kysymys kuin pelkästään materiaalivalinta.

Artikkeli pohjautuu tutkimukseen (Puuta näkyvissä! Puurakentamisen ulkoisvaikutukset asukkaiden ja muiden toimijoiden käsityksiin alueesta), joka on saanut rahoitusta ympäristöministeriön Kasvua ja kehitystä puusta -tukiohjelmasta.

\section{KIRJALLISUUS}

Arkkitehti, numero 6/1972.

Asuntokanta. Asuntoaloitukset talotyypeittäin. (10.12.2019). https://www.rakennusteollisuus.fi/ Tietoa-alasta/Talous-tilastot-ja-suhdanteet/Kuviopankki/Asuntomarkkinat/Asuntokanta/

Balgård, S. (1982). Täydennysrakentaminen puukaupungissa. Ympäristön analyysimenetelmä sopeutuvan rakentamisen avuksi (toim. H. Lehtonen). Hki: Rakentajain kustannus.

Bonta, J. P. (1979). Architecture and Its Interpretation: A Study of Expressive Systems in Architecture. New York: Rizzoli.

Böök, N. \& Seppovaara, J. (2008). Kirkosta savusaunaan. Puusta rakennettu Suomi. Helsinki: Otava.

Elementtirakentamisen historia. ([sd]). Betoniteollisuus ry. https://www.elementtisuunnittelu.fi/fi/ valmisosarakentaminen/elementtirakentamisen-historia

Hankonen, J. (1994). Lähiöt ja tehokkuuden yhteiskunta. Espoo \& Helsinki: Otatieto \& Gaudeamus.

Heikkinen, P. (2007). Puukaupunkiperinteestä nykyaikaan. Teoksessa M. Karjalainen \& R. Patokoski (toim.), Kotina puinen kaupunkikylä. Esimerkkejä moderneista puukaupungeista (s. 22-25). Helsinki: Puuinfo Oy ja Rakennustieto Oy. 
Heininen-Blomstedt, K. (2013). Jälleenrakennuskauden tyyppitaloalue. Paikan merkitykset ja täydennysrakentaminen [Väitöskirja, Helsingin yliopisto]. http://urn.fi/URN:ISBN:978-952-10-8693-9

Helsingin kaupunki, kaupunginkanslia. (s.d.). Asumisen ja siihen liittyvän maankäytön toteutusohjelma 2020. https://www.hel.fi/helsinki/fi/asuminen-ja-ymparisto/asuminen/kotikaupunki-helsinki

Helsingin yleiskaava. Kaupunkikaava - Helsingin uusi yleiskaava. Visio 2050. (2013). Helsingin kaupunki, kaupunkisuunnitteluvirasto. www.hel.fi/hel2/ksv/julkaisut/yos_2013-23.pdf

Helsingin yleiskaava. Kohti urbaanimpaa Helsinkiä. (2013). Helsingin kaupunki, kaupunkisuunnitteluvirasto. www.hel.fi/hel2/ksv/julkaisut/yos_2013-2.pdf

Jokelainen, K. (2002a). 1990-luvun puujulkisivujen estetiikasta. Teoksessa M. Karjalainen \& J. KoisoKanttila (toim.), Moderni puukaupunki. Puu ja arkkitehtuuri (s. 99-106). Helsinki: Rakennustieto.

Jokelainen, K. (2002b). Esimerkkejä täydennysrakentamisesta vanhaan puumiljööseen. Teoksessa M. Karjalainen \& J. Koiso-Kanttila (toim.), Moderni puukaupunki. Puu ja arkkitehtuuri (s. 37-46). Helsinki: Rakennustieto.

Kaipiainen, M. (1998). Tiivis ja matala puurakentaminen. Helsinki: Ympäristöministeriö.

Kalakoski, I., Huuhka, S. \& Koponen, O.-P. (2020). From obscurity to heritage: Canonisation of the Nordic Wooden Town. International Journal of Heritage Studies, 26(8), 790-805. https://doi.org/10.1080/135272 58.2019 .1693417

Karhula, M. (2007). Käytännön asuntopolitiikkaa - oma talo Oulussa. Teoksessa M. Karjalainen \& R. Patokoski (toim.), Kotina puinen kaupunkikylä. Esimerkkejä moderneista puukaupungeista (s. 37-42). Helsinki: Puuinfo Oy ja Rakennustieto Oy.

Karjalainen, M. (2002). Suomalainen puukerrostalo puurakentamisen kehittämisen etulinjassa. [Väitöskirja, Oulun yliopisto]. http://urn.fi/urn:isbn:9514266188

Karjalainen, M. \& Patokoski, R. (2007). Kuinka hyvä moderni puukaupunki syntyy. Teoksessa M. Karjalainen \& R. Patokoski (toim.), Kotina puinen kaupunkikylä. Esimerkkejä moderneista puukaupungeista (s. 26-30). Helsinki: Puuinfo Oy ja Rakennustieto Oy.

Karjalainen, M., Suikkari, R. \& Koiso-Kanttila, J. (1999). Moderni puukaupunki -hanke. Uusien puumiljöiden kehittäminen. Oulu: Oulun yliopiston arkkitehtuurin osasto.

Koiso-Kanttila, J. (2002a). Suomalainen moderni puuarkkitehtuuri. Teoksessa M. Karjalainen \& J. KoisoKanttila (toim.), Moderni puukaupunki. Puu ja arkkitehtuuri (s. 89-98). Helsinki: Rakennustieto.

Koiso-Kanttila, J. (2002b). Uuden puurakentamisen haasteet. Teoksessa M. Karjalainen \& J. Koiso-Kanttila (toim.), Moderni puukaupunki. Puu ja arkkitehtuuri (s. 47-52). Helsinki: Rakennustieto.

Koiso-Kanttila, J. (2007). Puukerrostaloista puisiin asuinmiljöisiin. Teoksessa M. Karjalainen \& R. Patokoski (toim.), Kotina puinen kaupunkikylä. Esimerkkejä moderneista puukaupungeista (s. 6-11). Helsinki: Puuinfo Oy ja Rakennustieto Oy.

Kolbe, L. (2005). Kaupunki, metsäkaupunki, puu ja puutarha - esikaupunki innovaationa ja identiteettinä. Teoksessa T. Joutsivuo \& M. Kekäläinen (toim.), Kaupunkikuvia ajassa (s. 337-350). Helsinki: Suomalaisen Kirjallisuuden Seura.

Korpivaara, A. (2007). Monipuolisempaa asuinympäristöä. Teoksessa M. Karjalainen \& R. Patokoski (toim.), Kotina puinen kaupunkikylä. Esimerkkejä moderneista puukaupungeista (s. 12-18). Helsinki: Puuinfo Oy ja Rakennustieto Oy.

Korpivaara, A. \& Alapiha, J. (toim.). (2005). Tiivis ja matala korttelirakenne-asuntorakentamisen typologiaa. Helsinki: Ympäristöministeriö ja Rakennustieto Oy.

Lahti, P. (2002). Matala ja tiivis kaupunki. Helsinki: Ympäristöministeriö ja Rakennustieto Oy.

Lehtovuori, O. (1998a). Kehitys vaatii asumatyyppien monipuolistamista. Asu ja rakenna, (3), 28-30.

Lehtovuori, O. (1998b). Kaavoittajan ja talosuunnittelijan yhteistyötä tarvitaan. Asu ja rakenna, (4), 29-32.

Lehtovuori, O. (1998c). Kaupunkiomakotitalo - uusi haaste yhdyskuntasuunnitteluun. Asu ja rakenna, (5), 23-25.

Lehtovuori, O. (1998d). Vaihtoehtoja kerrostaloasumiseen. Asu ja rakenna, (6), 15-16.

Lilius, H. (1985). Suomalainen puukaupunki. Trästaden i Finland. The Finnish Wooden Town. Rungsted Kyst: Anders Nyborg a/s.

Lilius, J. (2019). Why Are Families Staying in the City? Teoksessa J. Lilius, Reclaiming Cities As Spaces of Middle Class Parenthood (s. 47-65). Palgrave Macmillan. https://doi.org/10.1007/978-981-10-9010-3 
Mahoney, J. (2000). Path Dependence in Historical Sociology. Theory and Society, 29(4), 507-548. https://doi. org/10.1023/A:1007113830879

Manninen, R., \& Holopainen, T. (2006). Townhouse. Kytketty omatonttinen pientalo kaupungissa, lähtökohtia ja tavoitteita. Helsingin kaupunkisuunnitteluvirasto.

Manninen, R., \& Puustinen, S. (2002). Tiivistä ja matalaa Helsingin seudulle. Tutkimus tiiviin ja matalan asuntotuotannon edellytyksistä ja esteistä. Helsinki: Rakennustieto Oy.

Moilanen, K. (2019). Massiivipuurakenteista sekä -tuotteista. Teoksessa M. Lakkala \& J. Pihlajaniemi (toim.), Moderni hirsikaupunki. Tutkimushankkeen loppuraportti (s. 116-129). Oulu: Oulun yliopisto. http://urn. fi/urn:isbn: 9789526223070

Mustonen, P. \& Lindblom, T. (2016). Kantakaupungissa asuu tyytyväisiä lapsiperheitä. Kvartti, (1/2016). https://www.kvartti.fi/fi/artikkelit/kantakaupungissa-asuu-tyytyvaisia-lapsiperheita

Mälkki, M. (2010). Kytketyt kaupunkipientalot ja urbaani rakentaminen. Teoksessa M. Norvasuo (toim.), Asutaan urbaanisti! Laadukkaaseen kaupunkiasumiseen yhteisellä kehittelyllä (s. 131-150). Espoo: Aalto yliopisto.

Niskanen, R. (22.11.2015). Kaupan ja kulttuurin Paavola - 1980-luvun suuri kaupunkimurros näkyi Lahdessakin. Etelä-Suomen Sanomat, s. 6.

Norvasuo, M. (toim.). (2008). Kaksitoista asumisen konsepti-ideaa. Teoksessa Asuttaisiinko toisin? Kaupunkiasumisen uusia konsepteja kartoittamassa (s. 325-357). Espoo: Aalto-yliopisto, Teknillinen korkeakoulu.

Peura, P., Grundahl, K., Berg, P. \& Pihlajanmaa, J. (2000). Puurakentaminen 1995-1998. Loppu- ja arviointiraportti. Helsinki: Tekes.

Puuinfo. (2019). Valmistuneet puukerrostalot 1996-Maaliskuu 2019. https://www.puuinfo.fi/articles/ valmistuneet-puukerrostalot

Puurakentamisen edistämisen ja ohjauksen keinot kaavoituksessa -opas. (2020). [s.l.: Suomen metsäkeskus]. https://puutuoteteollisuus.fi/images/pdf/oppaat-kirjat/puukerrostalorakentaminen-kasvuunkaavoitusopas.pdf

Rakennukset. (2004). Puu, (3), 4-29.

Rakennustietosäätiö RTS. (2002). RT 99-10779. Tiiviin puutaloalueen suunnittelu. Moderni puukaupunki [Ohjetiedosto]. https://www.rakennustieto.fi/rtnet/10779ee/10779.pdf

Rehunen, A., Ristimäki, M., Strandell, A., Tiitu, M. \& Helminen, V. (2018). Katsaus yhdyskuntarakenteen kehitykseen Suomessa 1990-2016. Suomen ympäristökeskus. https://helda.helsinki.fi/ handle/10138/236327

Ruonavaara, H. (2006). Historian polut ja teorian kartta - eli miten tutkia tapahtumaketjuja sosiologisesti. Teoksessa J. Saari (toim.), Historiallinen käänne. Johdatus pitkän aikavälin historian tutkimukseen (s. 34-63). Helsinki: Gaudeamus Kirja.

Salmela, M. (9.8.2005). Helsingin Lehtovuori on 2000-luvun puukaupunki. Tiivis kaupunginosa ei turhaan yritä jäljitellä vanhaa (Asumisen uudet ympäristöt 7). Helsingin Sanomat. https://www.hs.fi/ kaupunki/art-2000004328334.html

Sanaksenaho, P. (2017). Moderni koti. Pientaloasumisen ihanteet arkkitehtuuri- ja sisustusjulkaisuissa 1950-1960-luvuilla. [Väitöskirja, Aalto-yliopisto]. http://urn.fi/URN:ISBN:978-952-60-7702-4

Siikanen, U. (1996). Puurakennusten suunnittelu. Tarvikkeet ja rakenteet (3. p.). [Helsinki]: Rakentajain kustannus.

Sipiläinen, I. (2020). Katsaus teolliseen puurakentamiseen - puuelementit. Helsinki: Työ- ja elinkeinoministeriö. http://urn.fi/URN:ISBN:978-952-327-510-2

Straver-Nevalainen, M. (2006). Tiivistä ja matalaa asuntorakentamista Alankomaissa. Helsinki: Ympäristöministeriö ja Rakennustieto Oy.

Suikkari, R. \& Salovaara, J. (2007). Asukaspalaute opettaa. Teoksessa M. Karjalainen \& R. Patokoski (toim.), Kotina puinen kaupunkikylä. Esimerkkejä moderneista puukaupungeista (s. 43-51). Helsinki: Puuinfo Oy ja Rakennustieto Oy.

Tolppanen, J., Karjalainen, M., Lahtela, T. \& Viljakainen, M. (2013). Suomalainen puukerrostalo. Rakenteet, suunnittelu ja rakentaminen. Helsinki: Opetushallitus ja Puuinfo. 
Tyni-Kylliö, K. \& Rajala, M. (12.11.2019). Linnanfältti. Moderni puukaupunki -hanke [pdf-diaesitys]. Turun kaupunki, Kaupunkisuunnittelu ja maaomaisuus.

Vahtikari, T. (2007). Miten Vanhasta Raumasta tuli maailmanperintökohde? Teoksessa O. Tuomi-Nikula \& E. Karhunen (toim.), Kotina suojeltu talo. Arkea, elämää ja rakennussuojelua Suomessa ja Saksassa (s. 97-117). Pori: Turun yliopisto, kulttuurituotannon ja maisemantutkimuksen laitos.

Ympäristöministeriö ja Puuinfo. (2019). Suunnitteilla ja rakenteilla olevat suomalaiset puukerrostalohankkeet 11/2019 [Suomalainen puukerrostalohankekanta]. https://puuinfo.fi/rakenteet/ yhdistelmarakenteet/puukerrostalohankekanta/ 